\title{
Tobacco use among Romanian youth
}

\author{
Lucia M. Lotrean, MD,(1) Carmen lonut, MD, PhD, (1) Hein de Vries,PhD. ${ }^{(2)}$
}

\section{Lotrean LM, lonut C, Vries $H$. Tobacco use among Romanian youth. Salud Publica Mex 2006;48 suppI I:SI07-SII2.}

\begin{abstract}
This paper reviews data published between 1990 and 2006 regarding smoking prevalence as well as individual and contextual influences on the smoking behavior among Romanian young adults. Highlights include a consideration of multiple levels of influence, from intra-individual factors, such as demographic and cognitive factors, to social influences, such as families and peers, to the more macro, societal/cultural levels of influence, including advertising and tobacco-related policies The source of data is represented by articles and short information published in journals or in electronic format, legislation, statistics and are illustrated with pictures. Based on these data, recommendations for future smoking prevention and reduction actions for Romanian youth are taken.
\end{abstract}

Key words: tobacco use; youth; tobacco industry tactics; Romania

\author{
Lotrean LM, lonut C, Vries $\mathrm{H}$. \\ Consumo de tabaco en jóvenes rumanos. \\ Salud Publica Mex 2006;48 supl I:S I07-SI I 2.
}

\section{Resumen}

Se revisan datos publicados entre 1990 y 2006 sobre prevalencia de tabaquismo, así como influencias individuales y contextuales respecto al hábito de fumar entre adultos jóvenes rumanos. Los hallazgos incluyen una consideración de múltiples niveles de influencia, desde factores intraindividuales (por ejemplo, demográficos y cognitivos), influencias sociales (como familia y pares), hasta niveles de influencia macro sociales/ culturales (publicidad y políticas relacionadas con el tabaco, entre otros). La fuente de datos incluye artículos y notas breves publicadas en revistas científicas o en formato electrónico, leyes, estadísticas, y se ilustran con imágenes. Con base en estos datos, se establecen recomendaciones para acciones futuras de prevención y reducción del consumo de tabaco en jóvenes rumanos.

Palabras clave: consumo de tabaco; jóvenes; tácticas de la industria tabacalera; Rumanía
Tt is estimated that each year in Europe tobacco use is 1 responsible for more than 1.2 million deaths, 700000 of which occur in the countries of Central and Eastern Europe. ${ }^{1}$ In Romania smoking is responsible for more than 32000 of deaths annually. ${ }^{2}$ Particular concern is caused by the increasing trends in smoking prevalence among Romanian young adults, which call for comprehensive actions of smoking prevention and reduction among this group. ${ }^{3}$
The argument for smoking prevention among adolescents is based on the observation that if smoking does not start during adolescence, it is unlikely to ever occur and on data indicating that the probability of cessation among adults is inversely related to age at initiation. Even infrequent experimental smoking in adolescence significantly increases the risk of adult smoking as well as the risk of diseases and death. ${ }^{4}$

(I) Department of Environmental Health, University of Medicine and Pharmacy, Cluj-Napoca, Romania.

(2) Department of Health Education and Promotion, University of Maastricht, the Netherlands. 
In order to develop a comprehensive strategy regarding smoking prevention and reduction among Romanian youth, it is very important to make a clear diagnosis of the situation, to identify the factors which lead to this situation and the mechanisms that could help in tobacco control actions.

The objective of this paper is to review the data focused on Romanian adolescents' smoking behavior published between 1990-2006, in order to reveal the weaknesses and strengths of tobacco control targeting young adults in Romania. Based on these data, recommendations for future actions for smoking prevention and reduction for Romanian youth are made.

\section{Material and Methods}

This paper reviews data regarding smoking prevalence as well as individual and contextual influences on the smoking behavior among Romanian young adults. Highlights include a consideration of multiple levels of influence, from intra-individual factors, such as demographic and cognitive factors, to social influences, such as families and peers, to the more macro, societal/cultural levels of influence, including advertising and tobacco-related policies.

The data sources consist of articles and short papers published in journals or in electronic format, legislation, statistics, and are accompanied by illustrations.

\section{Smoking prevalence among Romanian young adults}

For many years in Romania there was a scarcity of published data regarding smoking prevalence among Romanian young adults. The few studies available were based on national representative surveys.

A study performed among 18-19 year-old school students as part of a national surveillance program regarding lifestyle of Romanian school students shows that between 1993 and 1999 smoking prevalence rose from 9 to $24 \%$ among girls and from 20 to $38 \%$ among boys. Unfortunately no clear definition of smoking used by the study is available. ${ }^{5}$

Several studies have recently documented the prevalence of smoking among Romanian young adults. According to The National Survey on Tobacco, Alcohol and Drugs, which is part of The European School Survey Project on Alcohol and other Drugs (ESPAD) carried out in $2003,64 \%$ of 16 year-old Romanian school students reported smoking at least once during their lifetime, being noticed an increase of $11 \%$ compared with the year 1999. ${ }^{3}$
The Global Youth Tobacco Survey (GYTS) carried out for the first time in Romania in 2003 shows that $56.7 \%$ of 13-17 year-old school students had ever smoked cigarettes and 23.2\% currently smoke cigarettes (smoked cigarettes at least once in the past month). ${ }^{6}$ These data are similar to those found in other former communist countries such as Slovakia, Slovenia, Serbia and Hungary. ${ }^{7}$

A general population based study from 2003 points out that $40.6 \%$ of the Romania young adults aged $14 / 24$ years old smoked at least 100 cigarettes during their lifetime. ${ }^{8}$

According to another study from 2004, smoking prevalence among general population aged $15-24$ years is $61.8 \%$ during lifetime and $32.9 \%$ within the past month previous to the survey. ${ }^{9}$

\section{Individual factors which influence smoking behavior}

\section{Sociodemographics}

Although historically the prevalence of smoking was higher among young men than young women, data from different western European countries have revealed that the rates of current smoking and initiation to smoking are approximately equal for the two groups. ${ }^{4}$ This pattern started to be found in some Central and Eastern European countries, such as Hungary and Serbia. ${ }^{7}$ In Romania smoking is still more frequent among boys than girls. The GYTS shows that $49.1 \%$ of young girls smoked at least once during lifetime and 19.7\% smoked in the month previous the survey, while smoking prevalence among boys was $65.1 \%$ during their lifetime, and $27.1 \%$ in the past month. ${ }^{6}$

A general population-based study presents that $29.8 \%$ of $14-24$ year-old Romanian girls smoked at least 100 cigarettes during their lifetime, while the figure was $50.6 \%$ of Romanian boys from the same age group. ${ }^{8}$ Nevertheless, in recent times gender differences are becoming less significant.

\section{Cognitive factors}

Different cognitive factors have been consistently found to be predictors of smoking onset in many studies from North America or Western European countries, ${ }^{4,10,11,12}$ but few data are available from Eastern European countries, including Romania.

Similar to their counterparts from other countries, Romanian adolescents often concentrate on the short-term benefits of tobacco use, neglecting its harmful effects. ${ }^{1,13}$ One in three Romanian young adults 15-24 years of age believes that smoking less than 10 cigarettes /day can 
not be dangerous to health. ${ }^{9}$ Smoking is mainly a social activity for them and a way of controlling their emotions such as stress and nervousness. ${ }^{13,14}$ Many of them do not have refusal skills, since the smoking prevention programmes in Romania were generally concentrated only on offering information on health effects of smoking. ${ }^{13,14}$

\section{Social influences}

In Romania smoking has a high social acceptance and Romanian young adults often see teenagers and adults smoking. The prevalence of daily smoking among general population older than 15 years is $31.3 \%$, while $62.1 \%$ of them smoked at least once during their lifetime. ${ }^{9}$

Parents and siblings' behavior and attitudes regarding smoking have been proved to be important factors in influencing smoking behavior of young adults. ${ }^{4,15} \mathrm{In}$ Romania almost two thirds of 13-17 year-old school students have at least one parent who is a smoker. ${ }^{6}$ Moreover, 9 out of 10 school students declared that they are exposed to passive smoking in their homes. ${ }^{6}$

This is not surprising, since other studies show that $54.6 \%$ of smokers aged $14-60$ years smoke at home in the presence of other non-smoking members of their family. ${ }^{8}$

Many studies from different countries proved that peer influence is an important factor associated with smoking behavior among teenagers. ${ }^{4,12}$ Since the prevalence of smoking among youth is high in Romania, many adolescents have friends and classmates who smoke and thus they are probably often confronted with cigarette offers and pressure to smoke from their peers. Actually, a study carried out among 15-16 year-old school students from Cluj-Napoca, a big town of Romania, shows that having friends who smoke is an important factor associated with smoking among Romanian teenagers. ${ }^{14}$

\section{Societal/cultural influences}

\section{Tobacco advertising and promotion}

After the fall of the communist regime in 1989, all Eastern European countries, including Romania, have suffered the invasion of transnational tobacco companies (TTC), which discovered new important markets in this part of the world.

As Philip Morris documents show (Bates No: 2500120503-0537) their strategy was to work very closely with high level officials and to impose the policy they wanted: ${ }^{16}$

"PM's strategy has been to work via top-level political contacts in Eastern European markets, notably in the Finance Ministries. PM is also making use of US diplo- matic missions in the Eastern Countries to convey our point of view. This effort is being done in coordination with our Washington office, while our monitoring and lobbying capabilities in EE are being beefed up."

One example that shows that this strategy adopted by all TTC is an effective one is the position of US ambassador Alfred Moses addressed in 1994 in audience at the grand opening of a new American cigarette factory near Bucharest, the capital of Romania: "I am sure that Camel and the other splendid products of the RJ Reynolds Tobacco Co. will prosper in Romania."

At the same time, transnational tobacco companies have started an aggressive campaign of promotion in Romania, including ample advertisement targeted to young adults as well as sponsorship of different social and cultural events for youth. Figure 1a presents a picture from a concert at a club in Bucharest, the capital of Romania, sponsored by the tobacco industry, where one of the singers was a girl from the audience.

Selling packages of cigarettes with less than 20 cigarettes (figure $1 \mathrm{~b}$ ), offering objects with a cigarette brand logo as well as free cigarette samples were other tactics used by the tobacco companies in Romania in the past 15 years.

GYTS shows that $22.2 \%$ of Romanian school students aged $13 / 17$ years old have an object with a cigarette brand logo and $11.6 \%$ were offered free cigarettes by a tobacco company representative. ${ }^{6}$

The tobacco companies have tried all the time to associate the image of smoking with the idea of freedom, success, wellness and a Western value system whose allure has been hard to resist for adolescents during their search for identity.

In spite of this, the tobacco companies denied that they promoted their products to young adults, and they even organized so-called smoking prevention programs. Phillip Morris Romania and British American Tobacco Romania launched in 2000 and 2001 the smoking prevention program "The decision is mine" (figure 1c). The main message of the program was that smoking is a decision of adults, provoking in this way the young adults, who want to be considered mature, to smoke. The program had the support of the Ministry of National Education, Ministry of Youth and Sports and Ministry of Health of that time.

\section{Tobacco control in Romania}

Legislation regarding tobacco advertising

After political changes from 1989, cigarettes were present practically in all mass media - on TV, radio, outdo- 


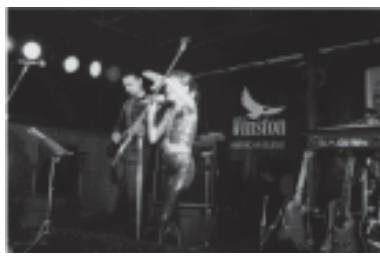

A. A tobacco industry sponsored concert from Bucharest, Romania in 2002
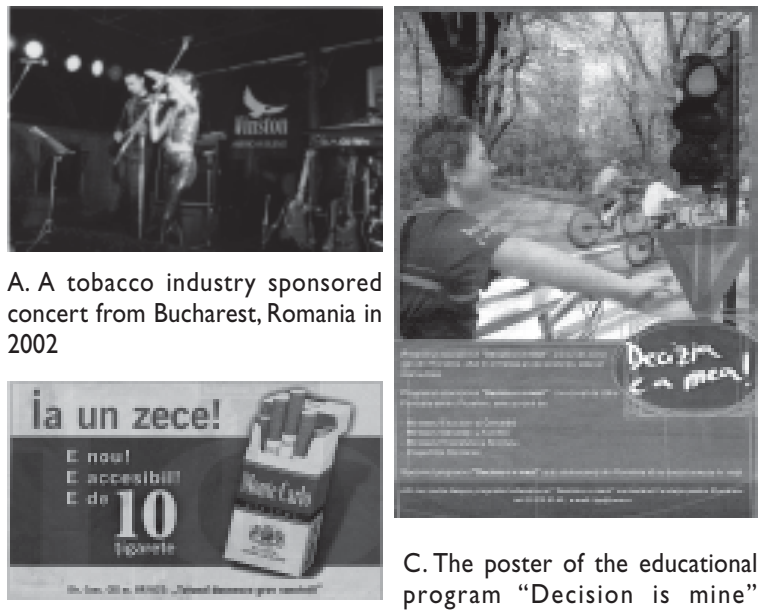

C. The poster of the educational program "Decision is mine" B. An advertisement for a ten- developed by the tobacco industry cigarette package with the slogan in Romania in 2000 and 200 I TAKE A TEN

Figure I. EXAMPLes of tobacco industry PROMOTION ACtivities IN Romania

or billboards, magazines, etc - with attractive spots, banners and articles.

Since 2000, advertisement was regulated partially, nowadays accepting some forms of indirect advertisement: outdoor, sponsorship for cultural events, advertisement inside journals, magazines and books. ${ }^{17,18}$

Cigarette availability for teenagers

In Romania there is a complete ban for sale of single or unpacked cigarettes and for selling of tobacco products to minors (less than 18 years of age). ${ }^{19}$ However, the law is very poorly enforced. GYTS show that $62.9 \%$ of teenagers who smoke buy cigarettes from a store. ${ }^{6}$ Also, the price of cigarettes in Romania was quite low in the past 15 years. ${ }^{16}$

Smoke-free areas in public places

In Romania smoking in public places (except pubs and restaurants), workplaces, health care buildings and public transportation is banned, but the law is not very well enforced. ${ }^{16,20,21}$ GYTS show that more than 8 out of 10 Romanian teenagers are exposed to cigarette smoke in public places. ${ }^{6}$

\section{Tobacco control actions and programs}

During the past 15 years, education for children, adolescents and young adults from Romania regarding tobacco use prevention had and still has weaknesses. Not enough informational and educational programmes were implemented. Often the programmes were implemented just occasionally and for a short period of time, evidencing the lack of long term strategies as well as the lack of evaluation of the programmes.

On the other hand, health professionals were not offering frequent smoking cessation counseling to their patients, whatever their age. The primary impediment to their accepting responsibility for tobacco control lies in their failure to recognize that their professional responsibility extends beyond the treatment and cure of tobacco-caused diseases and includes the prevention and cessation of tobacco use. This lack of recognition is reinforced by a medical compensation system that does not pay for counseling and cessation services.

In the past few years different governmental institutions such as the Ministry of Health and the National Agency against Drugs as well as non-governmental organizations were starting to get more actively involved in tobacco control actions. Several campaigns and programmes have been organized for smoking prevention and cessation, based upon previous similar international campaigns, funded by international, national and local organizations. These have included Celebrate World and National No Tobacco Days, campaign of information and education regarding passive smoking, and smoking prevention and cessation programmes for teenagers such as Quit and Win, SmokeFree Class Competition, I do not smoke, Adolescent smoking cessation and Protego. Table 1 describes the target group and content of these programmes.

As a signatory to the Framework Convention on Tobacco Control since the end of 2005, Romania is in the process of further strengthening its tobacco control legislation and activities.

\section{Conclusions}

After the change of the political regime in 1989, Romania was confronted with an aggressive promotion campaign developed by the transnational tobacco companies as well as with a lack of sustainability in the field of tobacco control. Under these circumstances, it is not surprising that the social acceptance and prevalence of smoking increased among Romanian young adults. From this point of view, Romania is a good example of how effective the tobacco industry strategies can be for penetrating a new market, including influencing political factors. A similar situation was encountered in other Eastern European countries. ${ }^{7}$

Hence, a comprehensive tobacco control strategy needs to be adopted and applied in Romania. One fo- 
Table I

\section{SMOKING PREVENTION AND REDUCTION PROGRAMS FOR ROMANIAN YOUNG ADULTS}

\begin{tabular}{|c|c|c|c|c|}
\hline Action/program & $\begin{array}{c}\text { Year } \\
\text { of implementation }\end{array}$ & Main organizers & Target group & Activities \\
\hline $\begin{array}{l}\text { World No Tobacco } \\
\text { Day }\end{array}$ & $\begin{array}{l}\text { Annually on } 31 \text { of } \\
\text { May }\end{array}$ & $\begin{array}{l}\text { Ministry of Health, National Agency against } \\
\text { Drugs, Non-governmental organizations }\end{array}$ & General population & $\begin{array}{l}\text { Campaigns of information and increasing of awareness } \\
\text { regarding smoking dangerous }\end{array}$ \\
\hline $\begin{array}{l}\text { National No Tobacco } \\
\text { Day }\end{array}$ & $\begin{array}{l}\text { Annually, on } 18 \text { of } \\
\text { November since } \\
2002\end{array}$ & $\begin{array}{l}\text { Ministry of Health, National Agency against } \\
\text { Drugs, Non-governmental organizations }\end{array}$ & General population & $\begin{array}{l}\text { Campaigns of information and increasing of awareness } \\
\text { regarding smoking dangerous }\end{array}$ \\
\hline $\begin{array}{l}\text { Mass media campaign } \\
\text { regarding passive } \\
\text { smoking }\end{array}$ & 2004 & Center for Health Policy and Services & General population & $\begin{array}{l}\text { Campaign on information on TV and billboards regarding } \\
\text { passive smoking }\end{array}$ \\
\hline $\begin{array}{l}\text { SmokefreeClass } \\
\text { Competition }\end{array}$ & $\begin{array}{l}2005 \\
2006\end{array}$ & $\begin{array}{l}\text { Non-governmental Organization Pure Air, } \\
\text { Romania; National Agency Against Drugs; } \\
\text { Ministry of Education and Research }\end{array}$ & $\begin{array}{l}\text { School teenagers } \\
\text { aged } 11 / 15 \text { years } \\
\text { old }\end{array}$ & $\begin{array}{l}\text { A few month competition, where the classes of pupils who } \\
\text { do not smoke during the competition and performed } \\
\text { different anti smoking activities can win different prizes }\end{array}$ \\
\hline $\begin{array}{l}\text { Adolescent smoking } \\
\text { cessation }\end{array}$ & 2005 & $\begin{array}{l}\text { Non-governmental Organization Pure Air, } \\
\text { Romania; National Agency Against Drugs } \\
\text { Ministry of Education and Research }\end{array}$ & $\begin{array}{l}\text { School teenagers } \\
\text { aged } 14 / 19 \text { years } \\
\text { old }\end{array}$ & Group counseling for smoking cessation \\
\hline Quit and Win & 2005 & $\begin{array}{l}\text { Non-governmental Organization Pure Air, } \\
\text { Romania; National Agency Against Drugs, } \\
\text { Ministry of Education and Research }\end{array}$ & $\begin{array}{l}\text { School aged } \\
\text { teenagers aged |4| } \\
19 \text { years old }\end{array}$ & $\begin{array}{l}\text { A few months competition, where the teenagers who } \\
\text { remain non smoker or quit smoking can win different prizes }\end{array}$ \\
\hline I do not smoke & 2006 & $\begin{array}{l}\text { Non-governmental Organization Pure Air, } \\
\text { Romania; National Agency Against Drugs, } \\
\text { University of Medicine and Pharmacy from } \\
\text { Cluj Napoca; Ministry of Education and } \\
\text { Research }\end{array}$ & $\begin{array}{l}\text { School aged } \\
\text { teenagers aged |3| } \\
\mid 5 \text { years old }\end{array}$ & Peer-led smoking prevention program on video \\
\hline Protego & 2006 & $\begin{array}{l}\text { National Agency Against Drugs; Ministry of } \\
\text { Education and Research }\end{array}$ & $\begin{array}{l}\text { Teenagers' parents } \\
\text { from several big } \\
\text { towns of Romania }\end{array}$ & $\begin{array}{l}\text { Counseling of parents about how to talk with their children } \\
\text { about substance use and abuse }\end{array}$ \\
\hline $\begin{array}{l}\text { Health education in } \\
\text { schools }\end{array}$ & Since 2002 & Ministry of Education and Research & School students & $\begin{array}{l}\text { Hours of health education regarding different issues, } \\
\text { including smoking }\end{array}$ \\
\hline
\end{tabular}

cus must be on educational smoking prevention programs, which should help Romanian young adults to develop skills to cope with pressure to smoke and with challenging situations. Programs that motivate and help smoking adolescents to quit smoking must be also implemented for Romanian young adults, since many of them are already regular smokers.

As several studies from different countries showed, ${ }^{21-23}$ ban on tobacco advertising and tobacco industry promotional activities, restrictions of smoking in public places, enforcing a smoke-free schools policy, and increase of cigarette price could effect important benefits in preventing and decreasing smoking among Romanian adolescents. Mass media could be also a useful ally in attempts of promoting a non-smoking culture among Romanian young adults.
Regular surveys should also be performed to monitor the situation and the effectiveness of tobacco control programs, campaigns, and actions.

On the way to integration to the European Union, the Romanian legislation has to be harmonized with the European one and in this moment different governmental as well as nongovernmental organizations should actively advocate and help to speed-up the application of the Framework Convention on Tobacco Control in Romania.

\section{Acknowledgements}

The authors thank Mr. Cornel Radu Loghin from the nongovernmental organization Pure Air, Romania for his help in the process of gathering information for this article. 


\section{References}

I.World Health Organization .The European Report on Tobacco Control Policy. Copenhagen:WHO Regional Office for Europe, 2002. 2. Shafey O, Dolwick S, Guindon GE, ed. Tobacco Control Country Profiles 2003. Atlanta, GA:American Cancer Society, 2003.

3. Romanian Ministry of Health. The European School Survey Project on alcohol and other drugs. Bucharest:The Ministry, 2004.

4. Tyas LS, Pederson L. Psychosocial factors related to adolescent smoking: a critical review of the literature. Tob Control 1998; 7:409-420 5. Bucur GE. Starea de sanatate a elevilor.Viata Medicala 1999;26:I. 6. National Centre for Chronic Disease Prevention and Health Promotion. Global Youth Tobacco Survey; available on the web page of National Centre for Chronic Disease Prevention and Health Promotion http://www.cdc.gov/tobacco/global/GYTS/factsheets/2004/pdf/ Romania_factsheet2004.pdf. Accessed 6 February 2006.

7. National Center for Chronic Disease Prevention and Health Promotion. Global Youth Tobacco Survey; available on the web page of National Centre for Chronic Disease Prevention and Health Promotion http://www.cdc.gov/tobacco/global/gyts/GYTS_countryreports.htm. Accessed 6 February 2006.

8. Center for Health Policies and Services. Fumatul si sanatatea publica in Romania. Cunostinte, atitudini si practici legate de consumul de produse din tutun in randul populatiei generale din Romania. [Smoking and public health in Romania. Knowledge, attitudes and practices regarding tobacco use among general population in Romania] Bucharest: The Center, 2004.

9. Abraham P et al. Prevalenta consumului de droguri in Romania 2004. [Prevalence of drug use in Romania]. Bucharest: National Agency against Drugs, 2005.
10. Holm K, Kremers S, De Vries H.Why do Danish adolescents take up smoking? Eur J Public Health 2003; 13: 67-74.

II. Markham WA et al. What determines future smoking intentions of I 2 to 3 year old UK African-Caribbean, Indian, Pakistani and white young adults? Health Educ Res 2004; 19:15-28.

12. Conrad KM, Flay BR, Hill D. Why children start smoking cigarettes: predictors of onset. Br J Addict 1992; 87: I7 I I-I724.

13. Laza V, Lotrean L. Smoking among Romanian young adults. ENYPAT Newsletter - Interaction 2003; 28: 16.

14. Lotrean L, lonut C, De Vries H.Why do Romanian adolescents smoke? Cluj Napoca, Romania: Proceedings of Jubilee Scientific Meeting, 2005:60

I5. De Vries H, Engels R, Kremers S, Wetzsel J, Mudde A.. Parents and friends' smoking status as predictors of smoking onset: findings from six European countries. Health Educ Res 2003; 18:627-636.

16. Radu-Loghin C. Romania-political mapping and tobacco control strategy in tobacco control. Available on the web page of Open Society Institute; http://www.policy.hu/radu/.Accessed 9 February 2006.

17. The Official Gazette of Romania no. 359, Law no. I48/2000, Romania. 18. The Official Gazette of Romania no. 534, Law no. 504/2002, Romania. 19. The Official Gazette of Romania no. 165, Law no. 55/1999, Romania. 20. The Official Gazette of Romania no. 435, Law no. 349/2002, Romania. 21. Trofor A, Loghin CR. Fumatul de la obicei la boala. [Smoking from habit to disease] lasi, Romania:Tehnopress, 2004.

22. Wakefield M, Chaloupka F. Effectiveness of comprehensive tobacco control programmes in reducing teenage smoking in the USA. Tob Control 2000; 9:177-186

23. Lantz M. Paula-Investing in youth tobacco control: a review of smoking prevention and control strategies, Tob Control 2000; 9:47-63 